\title{
Books in Review
}

SUGGESTIONS OF ITEMS SUITABLE FOR REVIEW ARE ENCOURAGED, AND publishers are urged to send copies of works of bibliographical interest to the Review Editor. I am always pleased to hear from qualified individuals willing to review publications in their fields of interest. Prospective reviewers should consult the Books Received section in the recent issues of the Papers and the lists of books that appear periodically in the B.S.C. Bulletin.

David B. Kotin, Review Editor, Papers of the Bibliographical Society of Canada, Canadian History Department, Metropolitan Toronto Library, 789 Yonge Street, Toronto, Ontario M4W 2 G8

American Diaries: An Annotated Bibliography, p. Ioо Books, Manuscripts, and the History of Medicine, p. Io2 The Canadian Military Experience 1867-1983, p. I03 Canadian Studies: Papers Presented at a Colloquium, p. Io5 Catalogue collectif des impressions québécoises, p. Io6 Collected Poems of Raymond Souster: Bibliography, p. Io8 European Americana: A Chronological Guide, p. Io9

An Index to 'Acadiensis, 'p. I I 2

Ocean, Paper, Stone, p. I I 3

Thinkers of the Twentieth Century, p. I I4

A Victorian Authority, p. I 6

Views and Viewmakers of Urban America, p. I 7

American Diaries: An Annotated Bibliography of Published American Diaries and Journals, Volume 1: Diaries Written from 1492 to 1844.

[Edited by] Laura Arksey, Nancy Pries, and Marica Reed. Detroit: Gale Research Co., I983. xviii, 3 I I p., cloth, \$74.00 ISBN 0-8 I03-I800-8

The publication of the first of this two-volume guide to American diaries demonstrates the present generation's continued fascination with this underrated literary 